\title{
Avian Leukemia Sarcoma Virus
}

National Cancer Institute

\section{Source}

National Cancer Institute. Avian Leukemia Sarcoma Virus. NCI Thesaurus. Code C14332.

A type $\mathrm{C}$ avian retrovirus 